\title{
Coal fires burning around the world: Opportunity for innovative and interdisciplinary research
}

Glenn B. Stracher, Division of Science and Mathematics, East Georgia College, Swainsboro, Georgia 30401, USA, stracher@ ega.edu

\section{INTRODUCTION}

Coal-bed and culm-bank fires are formidable forces of nature ignited by natural phenomena, including lightning strikes and forest fires, or by human-related activities like mining accidents or burning trash in abandoned mines. Spontaneous combustion due to exothermic reactions in coal exposed during mining is especially problematic, making further mining dangerous, while polluting surrounding communities (Fig. 1; Stracher and Taylor, 2004).

\section{COAL FIRES IN TIME AND SPACE}

Uranium-thorium/helium ratios and fission-track dates from detrital zircons in clinker and unconformable relationships between baked and unbaked sedimentary rocks demonstrate that coal fires occurred naturally in the geologic past, dating as far back, for example, as the Pliocene in the Powder River basin of the United States (Heffern and Coates, 2004) and the Pleistocene in northwest China (Kroonenberg and Zhang, 1997).

People have mined coal for heating and cooking for thousands of years. Although written accounts of coal fires date to at least the time of Alexander the Great (Stracher et al., 2005), the worldwide proliferation of these fires has increased dramatically since the industrial revolution, especially in the major coal-producing countries, including China, the United States, India, South Africa, Russia, and Indonesia (Stracher and Taylor, 2004). Currently, thousands of coal fires are burning-some for centuries and many uncontrollably, with flames as high as 20 $\mathrm{m}$ and temperatures exceeding $1000{ }^{\circ} \mathrm{C}$-from eastern Asia and northern China into the coal basins of Russia, Europe, Africa, north and south America, and Australia. The economic losses are enormous, estimated at US\$125-250 million in China, and it's projected that over US\$651 million will be necessary to contain or extinguish coal fires in the United States. In India, $\sim 1453$ million tons of coal are locked up in 70 fires in the Jharia coalfield alone (Stracher, 2004, 2007a).

\section{THE EFFECTS OF COAL FIRES}

\section{Constructive}

Coal fires are constructive in that they transform landscapes, frequently generating new chemical products at the same time. Sinkholes, valleys, and slump blocks produced by volumereduced coal during burning; chemically altered or pyrometamorphic rocks; and paralavas are the most obvious features of ancient and modern fires. Red clinker, used for landscaping and construction, in addition to coal-tar deposits and the mineralized byproducts of combustion like godovikovite and voltaite that encrust active-gas vents and fissures, are the results of complex and poorly understood thermochemical processes (Fig. 2; Stracher et al., 2005; Stracher, 2007b).

\section{Destructive}

To most people, coal fires are destructive because they consume a valuable energy resource, destroy floral and faunal habitats, and promote human suffering as a consequence of heat, subsidence, and pollution. Field measurements and laboratory analyses reveal that during burning, these fires spew carbon monoxide, benzene, toluene, and dozens of other toxins into the atmosphere and soil, along with the greenhouse gases methane (during heating of the coal) and carbon dioxide (see recorded

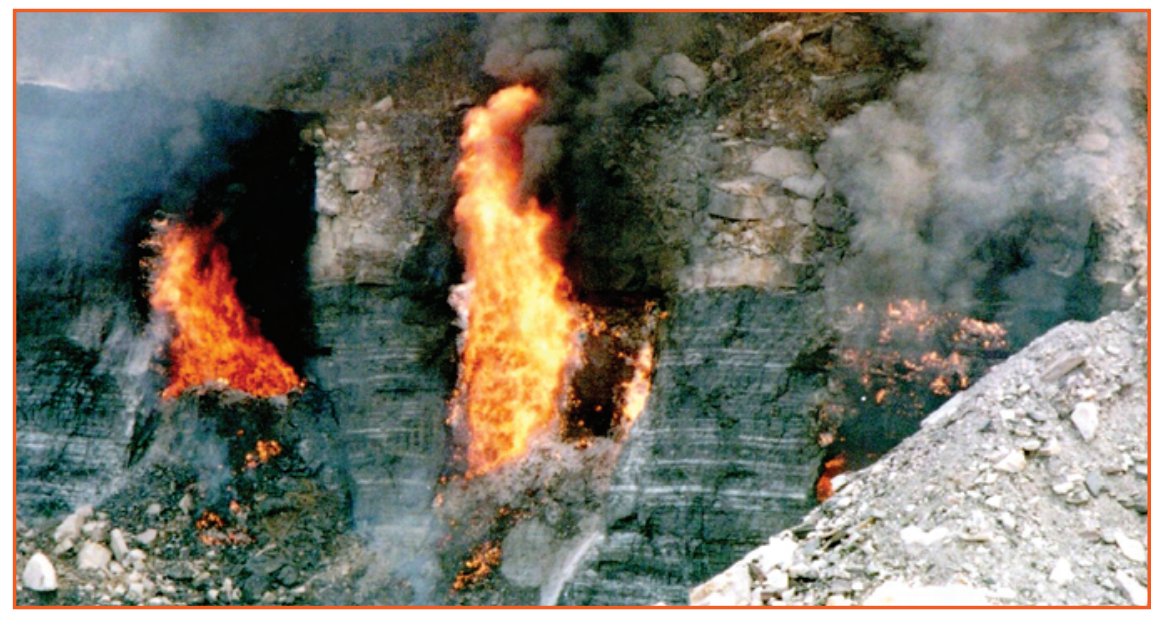

Figure 1. Open-pit mine fire near Dhanbad, Jharia Coalfield, India. Most Jharia fires ignite spontaneously, subsequent to mining. The middle flame is $\sim 7 \mathrm{~m}$ $(23 \mathrm{ft})$ high. Source: Daniel B. Sanger, GAI Consultants, Inc., Homestead, Pennsylvania, USA.

GSA Today: v. 17, no. 11, doi: 10.1130/GSAT01711GW.1 
values in the GSA Data Repository ${ }^{1}$ ). The per-annum global emissions of the components in coal-fire gas have never been quantified. However, the toxins have made people sick, sometimes fatally. Illnesses include carbon monoxide poisoning, arsenosis, fluorosis, bronchitis, stroke, lung cancer, pulmonary heart disease, and chronic obstructive pulmonary disease (Stracher and Taylor, 2004; Finkelman et al., 2002; Pone et al., 2007).

Acids, aerosols, and toxic-particulate matter released from coal fires may be transported long distances. In China, for example, such pollutants have adversely affected 88 cities, with the effects of acid rain spilling over into Japan, Korea, and the Philippines. Sulfate aerosols released from Jharia, India, fires have reduced by $15 \%$ the intensity of solar radiation reaching the Indian subcontinent. Over 200 coal fires in Pennsylvania have contributed to making it one of the leading acid-rain producers in the United States (Stracher and Taylor, 2004).

\section{WHY STUDY COAL FIRES?}

"Coal-fires science" has not been at the forefront of geologic research. The fires and their effects offer challenging opportunities for collaborative, innovative, and interdisciplinary research. For example, cost-effective methods for preventing, identifying, and extinguishing coal fires that are difficult or currently impossible to locate in underground workings need to be developed by utilizing current foam, liquid nitrogen, and newly developing fire-fighting technology. This requires collaborative expertise in economics, engineering, remote sensing, and environmental science, at the very least. Additionally, deciphering the origin of mineral assemblages formed from gas exhaled at vents or fissures associated with folded and faulted strata requires collaborative

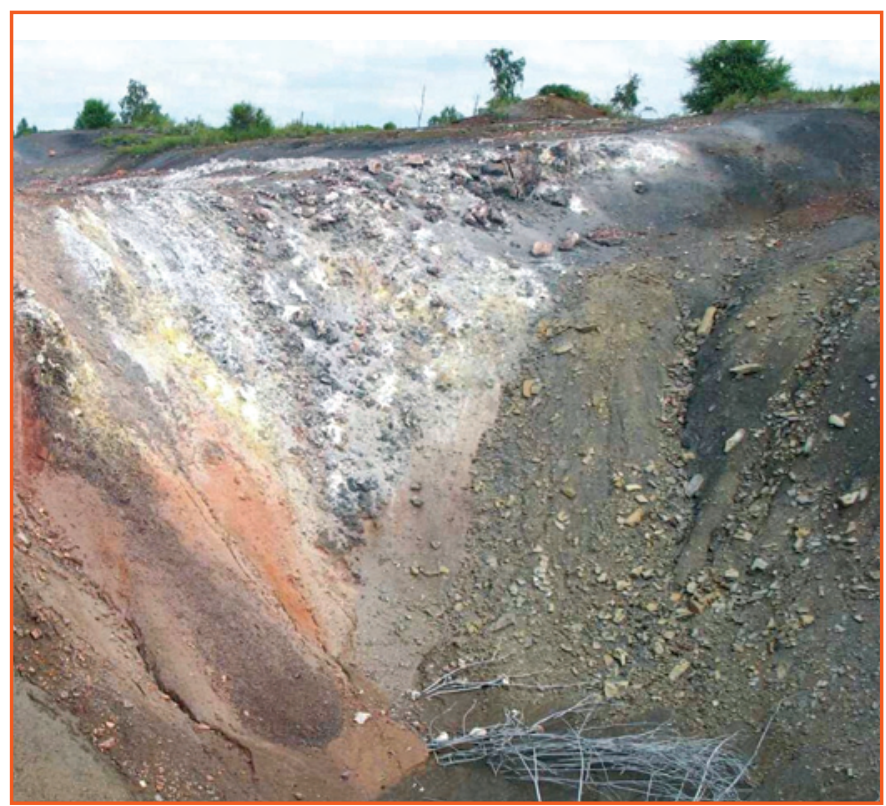

Figure 2. Fumarolic sulfur (yellow) and salammoniac (white) deposits from an active underground coal fire atop oxidized, pyrometamorphic debris (red) and coal-bearing shale (dark green to black) in a subsidence basin, Falcon Hills, Kuznetsk coal basin, western Siberia, Russia. Source: Ellina V. Sokol, Russian Academy of Sciences, Novosibirsk, and Ekaterina A. Nigmatulina, Novosibirsk State University. work in geochemistry, thermodynamics, mineralogy and petrology, structural geology, and instrumental analysis.

From a pedagogical perspective, currently active coal fires exemplify the uniformitarian foundation of geology because they can be studied in "real time." Mineral assemblages nucleated at active-gas vents and fissures, for example, are useful for establishing criteria for identifying paleo-fires (Stracher et. al., 2005).

\section{COAL-FIRES RESEARCH}

Coal-fires science is gaining international attention, generated by presentations at symposia and by field trips at international meetings, including the American Association for the Advancement of Science (AAAS) in Denver, Colorado, USA, in 2003; the Geological Society of America (GSA) in Denver in 2004, 2005, and 2006; and the International Conference on Coal Fires Research in Beijing, China, in 2005.

In commemoration of the AAAS meeting, a special edition of the International Journal of Coal Geology: Coal Fires Burning around the World: A Global Catastrophe presented the scientific and engineering communities in 2004 for the first time with a collection of diverse papers about these fires, including detection and containment procedures and health effects (Stracher, 2004). In December 2007, a GSA Reviews in Engineering Geology book: Geology of Coal Fires: Case Studies from Around the World, will cover a broader spectrum of topics including spontaneous combustion, greenhouse gases, mineralogy, petrology, the geophysics of coal fires, and public policy. It is my hope that this Groundwork article and these two volumes will serve as a "springboard" for generating interdisciplinary research in coal-fires science.

\section{REFERENCES CITED}

Finkelman, R.B., Orem, W., Castranova, V., Tatu, C.A., Belkin, H.E., Zheng, B., Lerch, H.E., Marharaj, S.V., and Bates, A.L., 2002, Health impacts of coal and coal use: Possible solutions: International Journal of Coal Geology, v. 50, p. 425443, doi: 10.1016/S0166-5162(02)00125-8.

Heffern, E.L., and Coates, D.A., 2004, Geologic history of natural coal-bed fires, Powder River basin, USA, in Stracher, G.B., ed., Coal Fires Burning around the World: A Global Catastrophe: International Journal of Coal Geology, v. 59, no. $1-2$, p. $25-47$

Kroonenberg, S.B., and Zhang, X., 1997, Pleistocene coal fires in northwestern China; Energy for early man, in van Hinte, J.E., ed., One million years of anthropogenic global environmental change: Proceedings of the ARA Symposium at the Royal Netherlands Academy of Art \& Sciences (KNAW), Project ID: 2-74690, p. 39-44.

Pone, J.D.N., Hein, K.A.A., Stracher, G.B., Annegarn, H.J., Finkelman, R.F., Blake, D.R., McCormack, J.K., and Schroeder, P., 2007, The spontaneous combustion of coal and its by-products in the Witbank and Sasolburg coalfields of South Africa: International Journal of Coal Geology, v. 72, p. 124-140, doi: 10.1016/ j.coal.2007.01.001.

Stracher, G.B., ed., 2004, Coal Fires Burning around the World: A Global Catastrophe: International Journal of Coal Geology, v. 59, no. 1-2, p. 1-151.

Stracher, G.B., ed., 2007a, Geology of Coal Fires: Case Studies from Around the World: Reviews in Engineering Geology, v. XVIII, doi: 10.1130/2007.4118(06) (in press).

Stracher, G.B., 2007b, The origin of gas-vent minerals: Isochemical and masstransfer processes, in Stracher, G.B., ed., Geology of Coal Fires: Case Studies from Around the World: Reviews in Engineering Geology, v. XVIII, doi: $10.1130 / 2007.4118$ (in press).

Stracher, G.B., and Taylor, T.P., 2004, Coal fires burning out of control around the world: Thermodynamic recipe for environmental catastrophe, in Stracher, G.B., ed., Coal Fires Burning around the World: A Global Catastrophe: International Journal of Coal Geology, v. 59, no. 1-2, p. 7-17.

Stracher, G.B., Prakash, A., Schroeder, P., McCormack, J., Zhang, X., Van Dijk, P. and Blake, D., 2005, New mineral occurrences and mineralization processes: Wuda coal-fire gas vents of Inner Mongolia: The American Mineralogist, v. 90, p. 1729-1739, doi: 10.2138/am.2005.1671. 